Article

\title{
The Corporate Social Responsibility of Family Businesses: An International Approach
}

\section{Gérard Hirigoyen and Thierry Poulain-Rehm*}

Institute of Research into Management of Organisations (IRGO), University Department of Business Administration, PUSG, University of Bordeaux, 35 Avenue Abadie, 33100 Bordeaux, France;

E-Mail: gerard.hirigoyen@u-bordeaux4.fr

* Author to whom correspondence should be addressed; E-Mail: tpr@u-bordeaux4.fr; Tel.: +33-556-009-720; Fax: +33-556-009-729.

Received: 4 May 2014; in revised form: 19 June 2014 / Accepted: 23 June 2014 /

Published: 9 July 2014

\begin{abstract}
This study analyzes the links between listed family businesses and social responsibility. On the theoretical level, it establishes a relationship between socioemotional wealth, proactive stakeholder engagement, and the social responsibility of family businesses. On a practical level, our results (obtained from a sample of 363 companies) show that family businesses do not differ from non-family businesses in many dimensions of social responsibility. Moreover, family businesses have statistically significant lower ratings for four sub-dimensions of "corporate governance", namely "balance of power and effectiveness of the Board", "audit and control mechanisms", "engagement with shareholders and shareholder structure", and "executive compensation".
\end{abstract}

Keywords: family business; corporate governance; human resources; social responsibility; stakeholders

JEL Classification: G30

\section{Introduction}

Milton Friedmans provocative statement, "The Social Responsibility of Business is to Increase its Profits" (Friedman, 1970 [1]) is an explicit reminder of the problem and assumed purpose of Corporate Social Responsibility (CSR) at a time when, encouraged by various intergovernmental, international 
and regional agencies ${ }^{1}$, many companies are seeking to develop a form of social responsibility [2]. As long ago as 1953, Bowen [3] thought it mandatory for companies to meet the expectations of society. Bowens concern was clearly to maximize social welfare rather than company profitability. Since then, numerous definitions of CSR have been proposed, including Jones (1980) [4], Wartick and Cochran (1985) [5], Wood (1991) [6], Blair (1996) [7], and McWilliams and Siegel (2001) [8]. In particular, Blair [7] defines a socially responsible firm as one that takes conscious decisions and reduces profits to benefit other stakeholders.

Although many empirical studies have sought to link social responsibility and financial performance (Margolis and Walsh, 2003 [9]; Makni et al., 2009 [10]), few have focused specifically on family businesses (De la Cruz Déniz Déniz and Cabrera-Suarez, 2005 [11]; Dyer and Whetten, 2006 [12]; Bingham et al., 2011 [13]), despite the fact that family businesses are a key part of the economic fabric, and their contribution to GDP is significant (Sharma et al., 1996 [14]; Neubauer and Lank, 1998 [15]; La Porta et al., 1999 [16]; Faccio and Lang, 2002 [17]; Morck and Yeung, 2004 [18]; Anderson and Reeb,003 [19]; PricewaterhouseCoopers, 2012 [20]). Fundamental questions related to our understanding of family businesses, their performance, functioning and relationships with stakeholders remain unanswered or have been only partially addressed. Do family businesses have a higher level of social responsibility than non-family firms, and if so, what are the underlying explanatory factors? In which areas do family businesses engage in CSR? Can a hierarchy be established? What does CSR translate into for the various stakeholders in the family business and what is its impact on the relationships between the family business and its stakeholders?

Here, we investigate whether family businesses have a higher level of CSR than non-family businesses. We adopt a broad concept of social responsibility, which takes into account multiple dimensions and the company's diverse stakeholders (human resources, shareholders, the community, the environment, suppliers, and clients). To improve the external validity of the results, we take an international approach, which is based upon a sample of companies representing different geographical areas. Our research makes both a theoretical and empirical contribution.

At the theoretical level, we establish a relationship between socioemotional wealth (SEW), proactive stakeholder engagement (PSE), and the social responsibility of family businesses. Recent literature explains the PSE of family businesses in terms of the creation and preservation of socioemotional wealth (Gomez-Mejia et al., 2012 [21]; Berrone et al., 2012 [22]; Cennamo et al., 2012 [23], Miller et al., 2012 [24]). For example, Gomez-Mejia et al. (2007) [25] explain empirical differences between family and non-family firms as an extension of the behavioral agency model, which postulates that choices made by a company depend on the reference point of its senior managers (Wiseman and Gomez-Mejia, 1998 [26]). In family businesses, the concept of SEW constitutes this reference point. For example, [22] claim that SEW is the dominant paradigm in the family business; they argue that it is the most

1. For example, the Organisation for Economic Co-operation and Development (OECD) Guidelines for Multinational Enterprises (written in 1976 and revised in 2000), which provide voluntary principles and standards for companies; the Global Reporting Initiative (GRI), launched in 1997 by the United Nations Environment Programme (UNEP), which seeks to establish guidelines and standardize norms for social and environmental reporting; the European Unions Green Paper (published in 2001 and again in 2007) to promote a European framework for Corporate Social Responsibility; and certifications, standards and labels such as the Social Accountability 8000 Standard or ISO 14001, which aim to measure the impact of corporate activity on the environment. 
important differentiator of the family firm as a unique entity, and explains their distinctive behavior. When there is a risk that it may be lost, or conversely, an opportunity to strengthen it, the family makes decisions that are not dictated by economic logic. The approach provides an integrated conceptual framework to explain the greater social responsibility of family businesses. The creation of SEW explains higher levels of PSE in both normative and instrumental terms: normative, because the family aims to be considered as a responsible actor; instrumental because gains in social legitimacy and enhanced reputation promote organizational efficiency and sustainability. On the empirical level, our concept of CSR integrates human and social dimensions, and adds other dimensions related to the quality of governance, business behavior, respect for stakeholders, and the environment.

The study implements an international comparative approach based on a sample of listed companies representing three geographic zones: Europe, North America, and the Asia-Pacific region. Our sample is taken from a database developed by the social rating agency Vigeo, and is based on a longitudinal analysis of data from 2001 to 2010.

The article is organized as follows: Section 2 presents the theoretical framework and hypotheses. Section 3 outlines the methodology. Section 4 presents the results and Section 5 offers a discussion of these results.

\section{Theoretical Framework}

\subsection{CSR and Proactive Stakeholder Engagement}

Many definitions of CSR exist in the literature. Although this has led some authors to argue that it is an elusive concept (Lee, 1987 [27]), which is poorly defined (Preston and Post, 1975 [28]), most consider it to refer to actions taken by businesses to improve societal, social and environmental conditions ([6,9]; Aguilera et al., 2007 [29]; Waddock, 2004 [30]). Given the lack of theoretical integration (Post, 1978 [31]; DeFillipi, 1982 [32]), CSR is increasingly analyzed in terms of the relationship between companies and their stakeholders, i.e., "any group or individual who can affect or is affected by the achievement of the organizations objectives" (Freeman, 1984 [33]).

Stakeholder theory sees businesses as nodes in complex relationships with their stakeholders. Consequently, many authors (e.g., Longo et al., 2005 [34], Abreu et al., 2005 [35], Uhlaner et al., 2004 [36] or Papasolomou et al., 2005 [37]) have favored this approach. More innovative research is based on "proactive stakeholder engagement" (PSE), which is defined as the willingness of businesses to anticipate the needs of their stakeholders and develop practices that meet these needs ([23]; Sharma, 2000 [38]).

Mitchell et al. (1997) [39] provide a deeper insight into the identification of stakeholders and their influence. They distinguish three stakeholder attributes: power (the ability of those who hold it to bring about the results they want), legitimacy (ethical, moral, and social demands) and urgency (the extent to which stakeholders accept delays in responding to their demands and criticality, i.e., the importance of the demand or the relationship). Based on these attributes, they identify seven stakeholder classes and establish a typology that orients the priorities of senior managers towards either stakeholders with the greatest number of attributes (definitive), or those with a combination of attributes requiring special attention (dominant). 
In later work they define the concept of "stakeholder salience", which determines the priority that managers give to meeting the demands of stakeholders, and apply it to the particular case of family businesses (Mitchell et al., 2011 [40]). They argue that such companies are characterized by the intersection of two institutions (the family and the business), and that the managerial response to stakeholder demands is more complex. In particular, power, legitimacy and urgency are specific to the business. Power is more normative than utilitarian. Legitimacy, which in the general managerial context is socially constructed, is based on ideas of inheritance. Finally, although in general, time considerations and the importance of stakeholders demands are somewhat independent in the management of an emergency, in family businesses they are linked by family ties and specific goals. Family firms pursue non-economic objectives (Chrisman et al., 2005 [41]) that create SEW [25]. These objectives are rooted in relationships between family members (Pearson et al., 2008 [42]) and are unique to the business. Given the traditional goals of profitability and growth, they may be mutually reinforcing, conflict, or be independent of each other (Gomez-Mejia et al., 2010 [43]; Zellweger and Nason, 2008 [44]). Finally, the desire to preserve SEW usually prevails over economic considerations.

\subsection{Proactive Stakeholder Engagement (PSE) and Socioemotional Wealth (SEW)}

Recent literature explains the PSE of family businesses in terms of the creation and preservation of SEW [21-24], which goes beyond simple financial objectives. The approach provides an integrated framework to explain the higher levels of social responsibility found in family businesses.

The concept of SEW was first proposed by [25] to explain empirical differences between family and non-family firms in certain areas, notably risk-taking. It extends the behavioral agency model [26], which postulates that choices made by the firm depend on the reference point of senior managers, who seek to preserve their investment. The authors of [25] apply this to the family business and argue that the reference point of family shareholder-managers is to maintain SEW, which explains why family business takes decisions that do not follow a completely economic logic. Berrone et al. (2010) [45] support the idea that family firms are more susceptible to institutional pressures exerted by the environment - all the more so as risk is offset by gains in social legitimacy. The authors of [23] claim that the creation of SEW and higher levels of PSE can be explained using both normative and instrumental arguments.

Normative arguments consider that PSE strategies are driven by the familys desire to be seen as a responsible citizen [12]. Kets de Vries (1977) [46], Schein (1983) [47], and Dyer (1986) [48] point out that the founders of family businesses see it as an extension of themselves and the company reflects their fundamental values (Chrisman et al., 2007 [49]). Cennamo et al. [23] (following Westhead et al., 2001 [50]) suggest that the firm is a mirror that reflects the self-esteem of family members. Similarly, Brickson (2005) [51] argues that firms whose identity consists of reciprocal commitments and personal relationships are oriented towards increasing the well-being and maximizing the wealth of a group that is larger than the firm itself. Baron (2008) [52] notes that altruism can dominate the family firm, and guide decision-making. Under these conditions, actions towards stakeholders are motivated by a broad concept of welfare. Finally, family members who are deeply rooted in their community are more concerned about environmental degradation and social problems [23].

Instrumental arguments relate to the hope of businesses that gains in social legitimacy and reputation will promote efficiency and consequently sustainability; in this case, societal performance 
increases the company's competitiveness (Jiao, 2010 [53]). McGuire et al., (2012) [54] underline that interactions between the family and the business make the issue of reputation particularly sensitive. Firms' investments in their reputational capital create value with their key stakeholders (Fombrun, 1996 [55]). Cennamo et al. [23] note that these "goodwill" reserves act as an insurance to protect trust in the company, which is all the more important when families concentrate their capital in a single organization. Moreover, Cennamo et al. [23] and Berrone et al. [45] highlight the desire of the family to transmit the business to future generations, while for others the firm symbolizes tradition (Tagiuri and Davis, 1992 [56]). Therefore, the preservation of SEW implies a long-term investment in order to ensure that this tradition is passed on to future generations.

The PSE of family businesses is at least partially explained by the homogeneity of their value system, which emphasizes affective relationships, solidarity, loyalty, trust in the environment, and in their own abilities ([40]; Chami, 2001 [57]). An analysis in terms of social capital helps to understand the importance of the social dimension. Bourdieu (1986) [58] emphasizes that social capital consists of actual or potential resources that are linked to a durable network of institutionalized relationships of mutual recognition and respect. The family invests not only its financial wealth in the company, but also its human capital and its honor, even more so when the company bears the family name [23]. Consequently, the network of relationships is an asset that may be turned into organizational capital, and a source of value creation (Nahapiet and Ghoshal, 1998 [59]). This explains why family businesses have a good reputation ([56]; Lyman, 1991[60]; Ward and Aronoff, 1991 [61]) and are keen to maintain it. Whetten and Mackey (2005) [62] explain the CSR of the family business by its need to forge an identity and project a positive image. The concern is to preserve the firms legacy, and has a qualitative dimension. Family businesses owners therefore regard unrest in the company or customer complaints as elements that may damage their business.

From this point of view, it is interesting to look at the concept of identification. This addresses the psychological factors at work, through the overlap between organizational and individual identity (Hogg, 2003 [63]; Hogg and Terry, 2001 [64]). The authors of [13] use the theory of organizational identity (Albert and Whetten, 1985 [65]) to explain the CSR of family businesses: such businesses orient their identity towards their stakeholders. Non-family firms make fewer engagements to socially responsible activities and only to the extent that they match individual identities. They consider stakeholders from a transactional perspective - in terms of the objective of creating value. In contrast, the identity of family firms is collective and relational; they create close links with stakeholders that are in line with their individual characteristics [13].

\subsection{Socioemotional Wealth and the FIBER Model}

The FIBER model was developed by [22] and provides an integrated framework for the analysis of the SEW of family businesses. It emphasizes five key dimensions: (i) Family control and influence; (ii) Identification of family members with the firm; (iii) Binding social ties; (iv) Emotional attachment of family members; and (v) Renewal of family bonds to the firm through dynastic succession. Based on this model, [23] argue that family firms engage proactively with both internal and external stakeholders. They engage with internal stakeholders in order to reinforce trust. This is all the more apparent as the family seeks to maintain control and influence the management of the firm, has a sense of the dynasty (which led it to adopt a long-term perspective), and values the company's reputation. 
It promotes engagements with external stakeholders (including those who have a more distant relationship with the firm) as the SEW of the family lies in its fundamental values, the strength of its internal social ties, and/or the emotional attachment of the firms owner.

\subsection{Hypotheses}

The literature review underlines the importance given by family businesses to their stakeholders and brings us to our hypotheses. Family shareholdings, which represent social capital, make it possible to structure and strengthen both internal and external links and relationships with principal stakeholders (Sirmon and Hitt, 2003 [66]). The commitment of managers to stakeholders appears to be a condition for sustainable development (Sloan, 2009 [67]).

The stakeholder approach [34-37] Jamali [68,69], led to the identification of the following six stakeholder categories: "human resources", "shareholders", “community”, “environment", "suppliers", and "consumers", based on the model developed by [39]. These categories are similar to those identified by [34] (employees, suppliers, customers, community) and [37] (employees, consumers, community, investors, suppliers, environment).

Finally, [23] explain the PSE of family businesses by distinguishing between internal and external stakeholders. Their work is based on that of [22], and we retain the distinction between internal and external stakeholders in the formulation of our hypotheses, which are as follows:

H1: Family businesses are more engaged in social responsibility with respect to internal stakeholders than non-family businesses. This hypothesis can be decomposed into two sub-hypotheses:

\section{H1.1: Family Businesses are More Engaged with Human Resources}

Family businesses are thought to have better management practices. They focus on personal and family values rather than business values, and are known for their integrity and commitment to human relations (Lyman, 1991 [60]; Koiranen, 2002 [70]; Aronoff, 2004 [71]), which leads to greater job stability during periods of crisis [2]. They are characterized by trust, motivation, increased loyalty (Tagiuri and Davis [72]; Allouche and Amann [73]; Steier, 2001 [74]), and flexible working practices (Goffee and Scase, 1985 [75]; Poza et al., 1997 [76]).

\section{H1.2: Family Businesses are More Engaged with Shareholders}

Family businesses are oriented towards the long term and aim to manage and increase the wealth of the family for the benefit of future generations (James, 1999 [77]; Hirigoyen, 2009 [78]). This long-term vision has a positive impact on the relationships between family businesses and their shareholders. Moreover, family businesses are characterized by better management of capital and resource allocation ([48]; Monsen, 1969 [79]; Astrachan, 1988 [80]).

H2: Family businesses are more engaged in social responsibility with respect to external stakeholders than non-family businesses. This hypothesis can also be decomposed as follows:

H2.1: Family Businesses are More Engaged with the Community

The idea of a virtuous circle between the engagement of family businesses to the community and value creation has been highlighted by [80]. They have a different relationship to risk and a better 
understanding of the resources available in their immediate environment; consequently they are better able to seize opportunities for growth and invest in sectors neglected by non-family firms. They not only contribute to increased employment, but also a dynamic economy and ultimately the well-being of the population. As a result, both economic and social developments are improved [15]. Vallejo Martos and Grand Torraleja (2007) [81] suggest a systemic approach in order to better understand the social responsibility of family businesses. They propose supplementing the three-circle model of Churchill and Hatten (1987) [82] (which describes the family, property, and the company) with community.

\section{H2.2: Family Businesses are More Engaged with the Environment}

The long-term vision of family businesses leads to a focus on sustainable development, which manifests itself as environmental, economic and social responsibility. Consistent with their values and the attention given to all their stakeholders, family businesses are likely to engage in sustainable and environmentally-friendly practices. At the firm level, the nonfinancial goals of family businesses include environmental actions [25,44].

\section{H2.3: Family Businesses are More Engaged with Suppliers and Customers}

The authors of [69] support the idea that family businesses are more attentive to the needs, expectations and reactions of their customers, and produce better-quality goods and services. This study found that the service provided to customers by these companies was marked by greater flexibility and adaptability; employees had greater autonomy in dealing with customer inquiries, which helped to strengthen the company's competitiveness. Similar arguments apply to suppliers $[25,44]$.

Our model examines the diverse expectations of stakeholders that family businesses attempt to satisfy, in terms of international instruments related to six domains, namely: human resources, human rights, corporate governance, community involvement, environment and business behavior. Other explanatory and control variables (financial performance, company size, business sector, and geographic zone) are integrated in order to take into account other factors that may influence CSR. These factors are outlined in the methodology.

\section{Methodology}

The methodology consists of measuring the influence of the family business on CSR. The analysis is based on a longitudinal analysis, carried out on explanatory data covering a period of ten years (2001-2010), to explain CSR observed in 2010, on a dataset of 363 listed companies, spread over three geographic zones (Europe, North America, and the Asia-Pacific region). The data was assessed using bivariate and multivariate analyses. The following sections describe the dataset, operationalization of variables and the statistical methodology.

\subsection{The Dataset}

The dataset was taken from Vigeos database. Vigeo is a social responsibility rating agency. It assesses the social, environmental and governance performance of businesses against the institutional and international standards of the United Nations (UN), the International Labour Organization (ILO), the Organisation for Economic Co-operation and Development (OECD), the World Trade 
Organization (WTO), and the European Union (EU). The agency provides analyses to investors and asset managers in European, Asian, and North American companies to assist them in choosing their portfolios. It also conducts social responsibility audits that provide decision-making assistance to the managers of companies or local authorities. Vigeos methodology fully integrates the recommendations of the ISO 26000 Guidelines for Social Responsibility ${ }^{2}$, which adopts a definition of social responsibility based upon the idea of respect for international standards of behavior. Its ratings therefore help companies to achieve ISO 26000 objectives and respond to stakeholders expectations (Crilly et al., 2012 [83]). The Vigeo model assesses performance against a set of social responsibility objectives that are clear, enforceable and weighted; the evaluation consists of complementary analyses and ratings are divided into four hierarchical levels using a formalized scoring system.

Overall, Vigeos database contains a total of 1800 listed companies, spread over three geographical areas (Europe, North America, and the Asia-Pacific region), which have all received at least one rating by the agency since 1999. However, the following restrictions were applied:

- Only companies that had a rating for 2010 were retained. This was to eliminate bias due to irregular ratings and ensure consistency;

- Banks, credit institutions, finance companies, insurance companies, holding companies and real-estate companies were not included because of their financial characteristics;

- Companies that had not been listed throughout the ten year period (2001-2010) were not included (e.g., newly listed companies, delisted companies, companies that became insolvent or were placed into receivership);

- Other companies, where missing data prevented the satisfactory execution of the analysis, were also removed;

These restrictions resulted in a final sample of 363 companies, of which 58 were identified as family businesses using the criteria described below.

\subsection{Variables}

\subsubsection{The Dependent Variable: Social Responsibility}

The overall dependent variable was global corporate social responsibility (CSRG). However, one of the major contributions of the current study is to assess the various dimensions of social responsibility; this approach is in contrast to other studies that favor a comprehensive approach or only focus on one particular dimension. The selected domains were based on the approach taken by Vigeo.

The Vigeo analysis concerns six dimensions of activity (human resources, human rights, corporate governance, community involvement, environment and business behavior) that are created from a total of 38 generic criteria. These criteria are evaluated according to 200 action principles that enable an assessment of managerial systems. Each criterion is weighted according to its sectorial relevance.

2 This standard, published by the International Standards Organization, integrates the following dimensions of social responsibility applicable to companies, namely: stable employment, pay, health and safety, training, collective and individual social relations, the fight against discrimination, social actions, relationships with suppliers, the impact on local development and respect for the environment. 
For each of the 35 sectors analyzed, the challenges are contextualized and weighted according to the degree of exposure of stakeholders and the risks or the competitive advantage they offer the company.

Moreover, for each of the 38 generic criteria, Vigeo examines in detail:

- Policies: business strategy, management processes, and the relevance of commitments based on a review of the content of stated policies and the extent to which they are adopted within the company;

- Deployment: the efficiency of policy implementation based on an examination of the resources made available, budgets and scope of application;

- Results: the performance achieved based on an analysis of quantitative performance indicators together with any complaints or disputes with stakeholders.

With these aims in mind, Vigeo uses multiple, traceable sources of information. Analysts first consult all publicly available documents (annual reports, sustainability reports, press releases, etc.), and contact the company for additional information. They then collect data from stakeholders (actors and observers on the ground, such as trade unions, NGOs and international organizations) to cross-check with information obtained from companies. They evaluate more than 250 indicators for each business, which make it possible to provide information and alerts on corporate commitments, performance, and risks on an ongoing basis.

The 38 generic criteria are consolidated into six domains.

(1) Human resources (HR): this dimension assesses industrial relations, employment relations, and working conditions;

(2) Human rights (HRTS): this dimension concerns respect for freedom of association, the promotion of collective bargaining, non-discrimination, the promotion of equality, the elimination of proscribed forms of work (child labor, forced labor), the prevention of inhuman or degrading treatment (such as sexual harassment), and the protection of privacy and personal data;

(3) Corporate Governance (CG): this dimension relates to the efficiency and integrity of governance. It not only concerns the independence and effectiveness of the Board of Directors (CG1), but also the effectiveness and efficiency of audit and control mechanisms (CG2). This notably applies to the risks of social responsibility, respect for the rights of (particularly minority) shareholders (CG3), and the transparency and rationality of executive compensation (CG4);

(4) Community Involvement (CIN): this dimension evaluates the effectiveness and integration of managerial engagement, the company's contribution to the economic and social development of its host country and human communities, specific engagements to manage the social impact of products and services and, finally, contributions to good causes in general;

(5) Environment (ENV): this dimension focuses on the protection, safeguarding, and prevention of environmental damage, and the implementation of an appropriate management strategy. It applies to eco-design, biodiversity protection and the intelligent management of environmental impacts throughout the life-cycle of products or services;

(6) Business Behavior (BB): this dimension takes into account the rights and interests of customers, the integration of social and environmental standards in the selection of suppliers throughout the supply chain, respect for competition rules, and the implementation of effective anti-corruption measures. 
Each dimension is rated on a scale of $0-100$. A score of 0 indicates little commitment to social responsibility, and poor, to very poor risk management. A score of 100 demonstrates a mature commitment to CSR.

\subsubsection{Explanatory and Control Variables}

Explanatory variables include family and financial variables. Control variables include company size, industrial sector and geographic zone. They are described in detail in the following sections.

\subsubsection{Explanatory Variables: The Family Business (FAM)}

How the family business is defined has a strong bearing on empirical results (Westhead and Cowling, 1998 [84]). Since the founding definition of Donnelley (1964) [85], researchers have generally taken one of two approaches. On the one hand, some studies base the definition on quantitative criteria, such as family control and ownership of capital (Barry, 1975 [86]). On the other hand, researchers have used qualitative criteria, measured in terms of the involvement and influence that the family has on management (Beckhard and Dyer, 1983 [87]), corporate culture, how the family interacts with the business (Boswell, 1972 [88]), or the transfer of the business to subsequent generations [82].

A family business can be considered as a business in which a shareholder group, united by family ties, holds a significant portion of the capital and voting rights, and exerts an effective influence on managerial decisions. Following the work of Chrisman and Patel (2012) [89], we used a binary variable to distinguish family and non-family firms. Therefore, a family business was considered to be any business in which at least $5 \%$ of the capital was held by the family and in which at least one family member has served as a member of the top management team [89].

The qualification of a business involved a detailed analysis of the shareholder structure, the composition of the Board of Directors and executive bodies. This information was taken from financial databases provided by Osiris (BvDEP) and Infinancials. ${ }^{3}$

\subsubsection{Explanatory Variables: Rate of Return on Assets (ROA)}

This performance measure is commonly used in studies on the relationship between CSR and financial performance (McGuire et al., 1988 [90]; Seifert et al., 2003 [91]). It has already been used in studies of family firms ([19]; Sraer and Thesmar, 2007 [92]; Villalonga and Amit, 2006 [93]). It was assessed as the ratio of net profit/total assets.

\subsubsection{Control Variables: Company Size (SIZE)}

The size of the company indicated the extent to which the company was humanized. It measured the influence of the hierarchical distance created by growth on the attention paid by management to staff problems. This variable was operationalized by the logarithm of the total number of full-time employees.

3 It would have been desirable to take into account the potential impact of the presence of the founder of the company on the way it is managed or the number of successive generations that had run the company. Unfortunately, the database that was used did not provide this, more qualitative, information. 


\subsubsection{Control Variables: Industrial Sector (SECT)}

Business performance must be assessed relatively, as it depends on the health of the sector and the financial flexibility it provides. Firms in the primary (extraction of natural resources, agriculture, fisheries, forestry and mining) and secondary sector (processing of raw materials) were combined into a single category. Those in the tertiary sector (service activities that do not fall into the first two categories) constituted a second category.

\subsubsection{Control Variables: Geographic Zone}

The impact of belonging to one of the three geographic zones (Europe, North America, the Asia-Pacific region) was tested. It is generally assumed that there are differences between the Anglo-Saxon and European (Rhenish) governance models, and the Japanese model is usually considered to be closest to the European model. The legal and political characteristics of national systems (La Porta et al., 1997 [94]), together with cultural and managerial factors (Aoki, 1984 [95]), are thought to influence governance systems and, more broadly, the operation of companies, which is likely to impact the level of engagement with stakeholders. Therefore, the following three dichotomous control variables, corresponding to the three geographic zones were included: EUR ( 1 if the company is in Europe, 0 if not); AME ( 1 if the company is in North America, 0 if not); ASIA ( 1 if the company is in the Asia-Pacific region, 0 if not).

To reduce the impact of economic fluctuations, the average value of each of the explanatory and control variables over a ten year period (2001-2010) was calculated.

\subsection{Statistical Analysis}

Students $t$-test for the comparison of means was performed on the variables described above.

Logit regressions measured the impact of the family nature of the business and the various explanatory variables on CSR. This method is an example of a probabilistic choice model, where the objective is to determine the probability of occurrence of an event, and the variables that influence it. Logit regressions are useful for many reasons. In particular, the method does not attempt to highlight the impact of each explanatory variable in isolation, but rather to reveal the interaction between variables. This is probably their greatest strength, compared to a discriminant analysis or a least squares regression, which are additive.

The aim was to determine the probability that family businesses constituted a group of firms with a high level of CSR. This was made possible by the transformation of continuous variables (CSR scores) into dichotomous variables (CSR supported or not). Consequently, the sample was grouped into two categories: companies with a low level of CSR (scores between 0 and 49), and those with a high or very high level (CSR scores between 50 and 100).

The predictive variables are both continuous and binary, as required by logistical regression models. Moreover, the maximum likelihood estimation led to the use of the "descending" option in order to remove non-significant variables based on variation of the likelihood.

The (generic) model was tested as follows:

$$
C S R=b_{0}+b_{1} F A M I+b_{2} R O A+b_{3} S I Z E+b_{4} S E C T O R+b_{5} E U R+b_{6} A M E+b_{7} A S I A
$$


where:

CSR (binary variable) $=$ CSRG $($ model 1$)$, RH $($ model 2$)$, HRTS $($ model 3$)$, CG (model 4), CG1 (model 5), CG2 (model 6), CG3 (model 7), CG4 (model 8), CIN (model 9), ENV (model 10), BB (model 11).

Statistical tests were carried out using SPSS software.

\section{Results}

Of the 363 companies, 211 were European, 127 were in North America, and 25 were in the Asia-Pacific zone. A total of 259 were in the primary and secondary sectors, while 104 were in the tertiary sector. Finally, 58 were categorized as family businesses.

Table 1 presents the descriptive statistics, Table 2 presents social responsibility scores using Students t-test for means comparison between family and non-family businesses and Table 3 presents Logit regression analyses of the social responsibility of family businesses.

Bivariate tests showed no statistically significant differences between the CSR of family businesses and others. Although the means for family businesses are higher in the dimensions of human resources, community involvement, environment, and business behavior, Students $t$-test was not significant. Thus, family businesses are not characterized by a greater engagement towards their stakeholders, whether internal or external.

However, family businesses had statistically significantly lower scores for the overall corporate governance variable, and each of its sub-dimensions. Scores were significant at the $1 \%$ level for corporate governance (CG), balance of power and effectiveness of the Board (CG1) and executive compensation (CG4), while audit and control mechanisms (CG3) and engagement with shareholders (CG3) were significant at the 5\% level. It is apparent therefore, that family businesses are characterized by a lower quality of governance, which gives rise to questions about power, and control of power exercised within them.

The principal result of the Logit analysis was that family businesses were less likely to operate a robust CSR policy ( -0.936 , significant at the $5 \%$ threshold). No statistically significant effect was observed for human resources, human rights, community involvement, environment and business behavior, which is entirely consistent with the bivariate tests. However, here again, it appears that family businesses are much less likely to have a high level of corporate governance (at the $1 \%$ threshold). This is particularly clear for the dimensions of balance of power and effectiveness of the Board (CG1) and executive compensation (CG4). Moreover, engagement with shareholders (CG3) and control and audit mechanisms (CG2) were negatively affected at the 5\% and 10\% thresholds, respectively.

Thus, not only are family businesses not characterized by higher levels of CSR, but their quality of governance appears to be lower.

Other explanatory variables, notably company size, also have an impact. This variable has a strong positive impact on CSR levels. It is significant at the $1 \%$ level for global social responsibility, human resources, human rights, balance of power and effectiveness of the Board, community involvement, environment, and business behavior. 
Table 1. Descriptive statistics and Pearson correlations of continuous variables.

\begin{tabular}{|c|c|c|c|c|c|c|c|c|c|c|c|c|c|c|c|}
\hline & Mean & SD & 1 & 2 & 3 & 4 & 5 & 6 & 7 & 8 & 9 & 10 & 11 & 12 & 13 \\
\hline CSRG—Social responsibility—overall performance & 39.51 & 10.608 & 1 & $0.813 * *$ & $0.740 * *$ & $0.388^{* *}$ & $0.403 * *$ & $0.339 * *$ & $0.138 * *$ & $0.243 * *$ & $0.657 * *$ & $0.857^{* *}$ & $0.741 * *$ & -0.051 & $0.455 * *$ \\
\hline HR-Human resources & 30.47 & 15.262 & $0.813 * *$ & 1 & $0.651 * *$ & 0.062 & $0.132 *$ & $0.112 *$ & -0.024 & -0.052 & $0.475 * *$ & $0.678 * *$ & $0.542 * *$ & $-0.174 * *$ & $0.357 * *$ \\
\hline $\mathrm{CG}$ - Corporate Governance & 50.83 & 13.466 & $0.388 * *$ & 0.062 & $0.116 *$ & 1 & $0.813 * *$ & $0.690 * *$ & $0.597^{* *}$ & $0.831 * *$ & $0.228 * *$ & $0.136^{* *}$ & $0.193 * *$ & $0.130 *$ & 0.057 \\
\hline CG1-Balance of power and effectiveness of the Board Directors & 48.88 & 19.033 & $0.403 * *$ & $0.132 *$ & $0.142 * *$ & $0.813^{* *}$ & 1 & $0.493 * *$ & $0.191^{* *}$ & $0.529 * *$ & $0.235 * *$ & $0.194^{* *}$ & $0.207^{* *}$ & 0.078 & $0.126 *$ \\
\hline CG2-Audit and control mechanisms & 60.25 & 13.786 & $0.339 * *$ & $0.112 *$ & $0.174 * *$ & $0.690^{* *}$ & $0.493 * *$ & 1 & $0.175 * *$ & $0.547^{* *}$ & $0.252 * *$ & $0.135 *$ & $0.236 * *$ & 0.101 & $0.110 *$ \\
\hline CG4-Executive compensation & 36.94 & 18.993 & $0.243 * *$ & -0.052 & 0.051 & $0.831 * *$ & $0.529 * *$ & $0.547 * *$ & $0.432 * *$ & 1 & $0.169 * *$ & 0.036 & $0.113 *$ & $0.157 * *$ & 0.000 \\
\hline $\mathrm{CIN}-$ Community involvement & 42.67 & 17.003 & $0.657 * *$ & $0.475 * *$ & $0.460 * *$ & $0.228 * *$ & $0.235 * *$ & $0.252 * *$ & 0.026 & $0.169 * *$ & 1 & $0.581 * *$ & $0.423 * *$ & $0.05-9$ & $0.314 * *$ \\
\hline ENV—Respect for the environment & 33.40 & 17.062 & $0.857^{* *}$ & $0.678 * *$ & $0.552 * *$ & $0.136^{* *}$ & $0.194 * *$ & $0.135 *$ & 0.008 & 0.036 & $0.581 * *$ & 1 & $0.555 * *$ & -0.072 & $0.463 * *$ \\
\hline BB-Business behavior & 43.34 & 11.988 & $0.741 * *$ & $0.542 * *$ & $0.601 * *$ & $0.193^{* *}$ & $0.207^{* *}$ & $0.236 * *$ & 0.020 & $0.113 *$ & $0.423 * *$ & $0.555^{* *}$ & 1 & -0.073 & $0.346^{* *}$ \\
\hline ROA-Rate of return on assets & 6.147 & 5.4627 & -0.051 & $-0.174 * *$ & -0.056 & $0.130 *$ & 0.078 & 0.101 & 0.062 & $0.157^{* *}$ & 0.059 & -0.072 & -0.073 & 1 & -0.097 \\
\hline SIZE —Company size & 4.2552 & 0.67870 & $0.455 * *$ & $0.357 * *$ & $0.306 * *$ & 0.057 & $0.126 *$ & $0.110 *$ & -0.079 & 0.000 & $0.314 * *$ & $0.463 * *$ & $0.346 * *$ & -0.097 & 1 \\
\hline
\end{tabular}
$* * * * * * *$ Significant at the $1 \%, 5 \%$ and $10 \%$ levels respectively.

Table 2. Social responsibility scores using Students $t$-test for means comparison between family and non-family businesses.

\begin{tabular}{|c|c|c|c|}
\hline & Mean for Non-Family Business & Mean for Family Business & Student $t$-tes \\
\hline CSRG: Social responsibility_overall performance & 39.45 & 39.81 & -0.237 \\
\hline HR: Human resources & 30.16 & 32.09 & -0.880 \\
\hline HRTS: Human rights & 44.32 & 42.86 & 0.795 \\
\hline CG: Corporate Governance & 52.00 & 44.67 & $3.870 * * *$ \\
\hline CG1: Balance of power and effectiveness of the Board & 50.07 & 42.60 & $2.763 * * *$ \\
\hline CG2: Audit and control mechanisms & 60.91 & 56.76 & $2.115 * *$ \\
\hline CG3: Engagement with shareholders & 59.21 & 52.59 & $2.307 * *$ \\
\hline CG4: Executive compensation & 38.68 & 27.83 & $4.072 * * *$ \\
\hline CIN: Community involvement & 42.43 & 43.93 & -0.617 \\
\hline ENV: Environment & 32.85 & 36.33 & -1.425 \\
\hline BB: Business behavior & 43.01 & 45.07 & -1.198 \\
\hline
\end{tabular}

$* * * / * * *$ Significant at the $1 \%, 5 \%$ and $10 \%$ levels respectively. 
Table 3. Logit Regression analyses of the social responsibility of family businesses.

\begin{tabular}{|c|c|c|c|c|c|c|c|c|c|c|c|}
\hline Variables & Model 1 CSRG & Model 2 HR & Model 3 HRTS & Model 4 CG & Model 5 CG1 & Model 6 CG2 & Model 7 CG3 & Model 8 CG4 & Model 9 CIN & Model 10 ENV & Model 11 BB \\
\hline \multirow{2}{*}{ CONSTANT } & $-11.372 * * *$ & $-12.262 * * *$ & $-4.909 * * *$ & $-2.221 * * *$ & $-2.329 * * *$ & -0.080 & $0.0480 * * *$ & $-2.507 * * *$ & $-5.117 * * *$ & $-7.076 * * *$ & $-4.552 * * *$ \\
\hline & 53.471 & 35.474 & 30.026 & 8.446 & 10.575 & 0.040 & 6.729 & 55.296 & 34.110 & 36.114 & 29.038 \\
\hline \multirow{2}{*}{ FAMI } & $-0.936 * *$ & & & $-1.465 * * *$ & $-0.940 * * *$ & $-0.662 *$ & $-0.756 * *$ & $-1.054 * * *$ & & & \\
\hline & 4.684 & & & 19.431 & 8.926 & 3.741 & 6.056 & 6.701 & & & \\
\hline \multirow{2}{*}{ ROA } & & $-0.095 * *$ & & $0.039 *$ & & & & $0.061 * *$ & & & \\
\hline & & 5.277 & & 3.187 & & & & 5.508 & & & \\
\hline \multirow{2}{*}{ SIZE } & $1.831 * * *$ & $1.783 * * *$ & $1.067 * * *$ & $0.413 * *$ & $0.453 * * *$ & & & & $1.057 * * *$ & $1.339 * * *$ & $0.797 * * *$ \\
\hline & 33.703 & 22.252 & 27.595 & 6.045 & 7.574 & & & & 29.063 & 27.297 & 17.934 \\
\hline \multirow{2}{*}{ SECT } & $-0.910 * *$ & $-1.643 * * *$ & $-1.012 * * *$ & & & & $0.670 * *$ & $0.722 * * *$ & & & \\
\hline & 5.614 & 10.569 & 12.042 & & & & 6.121 & 6.784 & & & \\
\hline \multirow{2}{*}{ EUR } & $2.866 * * *$ & $3.868 * * *$ & & $0.777 * * *$ & $0.754 * * *$ & $1.413 * * *$ & $0.404 *$ & $1.339 * * *$ & & & $0.555 * *$ \\
\hline & 32.320 & 14.056 & & 11.477 & 11.124 & 10.198 & 2.920 & 20.690 & & & 5.215 \\
\hline \multirow{2}{*}{ AME } & & & $-0.641 * *$ & & & $2.734 * * *$ & & & $-0.442 *$ & $-1.219 * * *$ & \\
\hline & & & 5.983 & & & 26.414 & & & 3.056 & 11.187 & \\
\hline \multicolumn{12}{|l|}{ ASIA } \\
\hline Chi-2 & $103.076 * * *$ & $94.796 * * *$ & $46.217 * * *$ & $34.816 * * *$ & $24.633 * * *$ & $34.513 * * *$ & $13.018 * * *$ & $35.861 * * *$ & $38.089 * * *$ & $47.666 * * *$ & $26.432 * * *$ \\
\hline$-2 \log$ Lik. & 252.890 & 188.785 & 408.649 & 468.406 & 477.597 & 327.109 & 441.848 & 363.946 & 425.394 & 302.502 & 426.910 \\
\hline
\end{tabular}

$* * * / * * *$ Significant at the $1 \%, 5 \%$ and $10 \%$ levels respectively. 
The influence of other variables is more nuanced. Industrial sector (SECT) has a mixed effect. Belonging to the tertiary sector has a negative impact on global social responsibility (at the $5 \%$ level) and on human resources and human rights (at the $1 \%$ level). However, the same conditions appear to have a positive effect on engagement with shareholders (at the 5\% level) and executive compensation (at the $1 \%$ level). Rate of return on assets (ROA) has a negative influence (at the $5 \%$ threshold) on the probability of developing socially responsible policies in the domain of human resources, but a positive influence in the domain of executive compensation (also at the $5 \%$ threshold).

Geographic variables merit particular attention. European companies (EUR) have a statistically significant probability of developing an active and robust CSR policy. The impact is significant at the $1 \%$ threshold for the global CSR indicator (CSRG), human resources (HR), and corporate governance (CG) and at the 5\% threshold for the business behavior dimension (BB). American companies (AME) are more likely to have a higher level of governance in the audit and control mechanisms dimension, which is statistically significant at the $1 \%$ level. Conversely, there is a negative impact on the likelihood of developing socially responsible policies related to the environment (at the $1 \%$ threshold), and human rights (at the 5\% threshold).

Consequently, all hypotheses are rejected.

\section{Discussion and Conclusions}

\subsection{Contributions}

This study of a sample of listed companies, showed that family businesses are not characterized by higher levels of CSR, based on the selected measures. There are no statistically significant differences between family and non-family firms in ratings of human resources, human rights, community involvement, environment and business behavior. Moreover, this is the first time, to our knowledge, that a study has highlighted a negative relationship between family companies and corporate governance, both as a constituent dimension of social responsibility and its various sub-dimensions (balance of power and effectiveness of the Board, audit and control mechanisms, engagement with shareholders and shareholder structure, and executive compensation). These results were obtained from a broad sample of companies spread over three geographic zones and are based on a business classification that distinguishes family businesses based on both their ownership structure and management mode.

The finding that family firms do not show a greater engagement towards their stakeholders contradicts theoretical predictions that their presumed closer relationship with stakeholders is at the origin of their economic success and superior performance [80]. It also qualifies the results of other empirical studies, notably those of Uhlaner et al. (2012) [96], who, based on a sample of small- and medium-sized Dutch businesses, showed a conditional influence of family businesses on their commitments, which favored environmentally-friendly practices. Similarly, while the study by [13], on a sample of large, publicly-traded S\&P 500 companies, partially confirms our hypotheses, it also suggests that in North America there is a positive relationship between family businesses and some dimensions of CSR - in particular those related to community initiatives and employee relations. Their results suggested that the effect increases with the level of family involvement in the business. 
For their part, Block and Wagner (2011) [97] argue that the effect of family ownership can differ across various CSR dimensions. Family firms can be responsible and irresponsible regarding CSR at the same time. Their results show that family ownership is negatively associated with community related CSR performance and positively associated with diversity-, employee-, environment-, and product-related aspects of CSR. They note the largest positive effect of family ownership on CSR performance exists with regard to product-related aspects of CSR.

Our results are more in line with the work of [11], who carried out a study on a sample of 612 small- and medium-sized Spanish companies, or that of [12], who have looked at a sample of large publicly-traded SandP 500 companies. Based on a sample of North American companies, [12] found no difference between family and non-family firms in terms of social initiatives for the period 1991-2000. Nevertheless, any differences or similarities in results must be treated with caution given the various contextual, geographical and temporal fields of investigation, and variations in measures of social responsibility.

Our observation that scores related to human resources and human rights are not higher in family firms is surprising, given the generally accepted view that they are more engaged in human relations [69-71]. Moreover, our results show that family businesses do not demonstrate greater engagement with employment relations, labor relations, working conditions, or respect for social rights.

Another surprising result is the similarity in scores relating to community involvement in family and non-family businesses. This does not support the idea that family businesses have a closer relationship with either host countries or their local communities, nor are they more engaged in managing the social impact of their products and services. It challenges the view that, due to their position at the heart of the community, they enjoy a special relationship with their environment (Uhlaner et al., 2012 [96]; Sharma and Sharma, 2011 [98]), and a sense of shared belonging with stakeholders, employees, customers and suppliers [11]. The observation that scores related to environment and business behavior are very similar is entirely consistent with previous work, although family businesses could be expected to be more responsive both to the environmental consequences of their production activities, and also to the needs, expectations and reactions of their customers [69].

Several factors may explain our results. First, there are some general factors. The dataset was composed of large, listed companies whose requirements, in terms of competitiveness and corporate governance, are very similar regardless of their shareholder structure or type of management. The life-cycle of family firms means that their managerial characteristics come to resemble those of non-family businesses. Such firms change significantly over time, from the first generation founding father, via sibling partnerships to the confederation of cousins (Ward, 1991 [99]). The influence of the family weakens with the appointment of external directors (either to head the company or as members of the executive committee) and as their share of capital decreases. These factors mean that both family and non-family listed firms (who evolve in the same economic, legal and regulatory environment) develop similar organizational structures and management styles. Being quoted on the stock exchange homogenizes behavior. In both cases, short-term concerns tend to dominate over long-term objectives. In these conditions, and consistent with traditional financial theory, the objective of shareholder value creation prevails. In this sense, our results confirm the convergence of corporate governance systems in listed companies. It may therefore be the case that differences in behavior are seen at the level of unlisted family firms; something that remains to be confirmed by further works. 
Secondly, there may be factors specific to family businesses. Such businesses are characterized by the family's engagement with them and the benefits they bring to the family, which risks becoming self-centered and inward-looking. The key objective of the family-run business is the preservation, development and transfer of their legacy. The family identifies with the company, shares and forms its values, and is committed to its growth for the benefit of future generations - a factor that sometimes leads to decisions that favor family members at the expense of other stakeholders.

On a theoretical level, it is interesting to analyze these results in the light of socioemotional theory [25,45], which is based upon the behavioral agency model [26]. On the one hand, our results seem to contradict those of [22], who investigated the conditions that encourage family companies to demonstrate PSE. On the other hand, they tend to confirm the conceptual analysis of Kellermanns et al. (2012) [100], according to which the five dimensions of SEW (family control and influence, identification of the family with the firm, binding social ties, emotional attachment of family members and transgenerational intentions) are associated with a lack of PSE. The authors of [100] draw upon affect infusion theory (Forgas, 1995 [101]; Loewenstein and Adler, 1995 [102]) to argue that SEW can be perceived as negatively or positively valenced, and high levels of SEW can be associated with poor levels of stakeholder care. They point out although family firms do not have an aversion to risk, they do have an aversion to the loss of SEW, which can lead to decisions that are unfavorable for stakeholders.

The utility function of the family shareholding is complex, as it leads to a trade-off between private consumption, the value of business assets (Mahérault, 1999 [103]), cash income over its lifetime, and the wellbeing of the next generation (Bhattacharya and Ravikumar, 1999 [104]). Basco and Perez Rodriguez (2011) [105] underlined the diversity of family businesses and established a typology of firms based on their orientation: "family oriented" businesses (which place greatest emphasis on the principles and values of the family in their decision-making, and give priority to its needs and objectives); "business oriented" companies (in which strategic decisions principally respond to the companys goals and its needs); and "family-business oriented" companies (which set priorities by finding a balance between the needs of the family and those of the company). This interpretation may explain why the interests of the family and the business impact the interests of various non-family stakeholders. This is all the more true, given that family shareholders run a significant personal risk resulting from both managerial decisions and the consequences of these decisions on their personal wealth and that of the family. Xiao et al. (2001) [106] showed that although family shareholders are exposed to individual risk, it is less relevant at the level of global business risk since there is little capacity to diversify their personal asset portfolio.

Moreover, it could be claimed that the birth of a family business brings with it agency costs associated with behavioral biases ([57]; Schulze et al. 2003 [107]). Following Habbershon et al. (2003) [108], Hirigoyen (2008) [109] highlighted the need to update the three-circle model of Gersick et al. (1997), which assumes that the behavior of actors involved in the family business is homogeneous and monolithic. The author of [109] suggests adding a fourth individual circle, to explicitly take into account the evolving preferences of individuals, which may give rise to behavioral biases. These biases are as much cognitive and emotional, as individual and collective. Differences in expectations between external stakeholders and the family can create cognitive agency costs. Altruism, in particular, is likely to alter managerial perceptions and limit their ability to monitor and effectively discipline family 
members, at the expense of other internal and external stakeholders. O'Boyle et al. (2012) [110] therefore argue that it is necessary to analyze the symbolic capital of the family shareholding and how it creates a particular competitive advantage; in particular they recommend refining the concept of the role of the family shareholding to take into account altruism, growth strategy, and leadership styles.

\subsection{Managerial Implications}

Various factors may so explain the weaknesses of family businesses according to our definition of governance. In our study this manifests as weaknesses in the balance of power and the effectiveness of the Board, audit and control mechanisms, engagement with (particularly minority) shareholders and the determination of executive compensation. Clearly, the emotional and cognitive biases highlighted by previous literature may have an impact on the remuneration of managers, which, like the recruitment of other family members, the evaluation of their performance, and their career progression is not necessarily guided by economically rational considerations. In family firms, the satisfaction of family interests seems to prevail over those of other stakeholders, in the matter of remuneration and other areas. Similarly, the rights of majority shareholders belonging to the family prevail over those of minority shareholders. These considerations may explain our finding that the Board of Directors is less efficient, and audit and control mechanisms are weaker in family firms. The Board of Directors is a key facet of corporate governance and its disciplinary role becomes more important as capital is controlled by the family (Charreaux and Pitol-Belin, 1990 [111]). The issue is significant: a study in the United States of over 80 family businesses run by at least the third generation, showed that the existence of an active board that was not controlled by the family was the most important element in the sustainability these companies [99]. Other empirical studies have shown that the performance and value of family firms are lower, relative to non-family businesses when the Board has relatively few independent directors (Anderson and Reeb, 2004 [112]). Other studies have shown a positive relationship between the proportion of independent directors and the existence of an audit committee, which is considered to be one of the factors for improving governance in family businesses (Chau and Leung, 2006 [113]). In family businesses the audit committee is composed of directors who are family members, and (depending on how capital and ownership is structured) by directors representing other shareholders (for example other businesses, banks, financial institutions, investment funds and pension funds) who hold a share of the capital and have objectives that are more financial than strategic. The more decisions are influenced by directors who are family members (and who attempt to preserve or enhance family control of the company's capital and management), the more the balancing power(s) of non-family directors is weakened. This is particularly true in companies where those who own the company's capital simultaneously exercise managerial and administrative functions.

However, in order to bring real added-value to the governance of this type of business, the Board of Directors must play an active role in monitoring managerial actions, checking the quality of internal control procedures, and succession planning. It must also act as a strategic think tank that assesses confidential information and helps in decision-making, while at the same time operating as the interface between the business and the family. It is clear that the Board cannot properly carry out these functions when there is confusion between the roles of shareholders, directors and managers who are family members. Nevertheless, this does not negate the role of family or non-independent directors, 
who, according to the resource-based view (Wernerfelt, 1984 [114]), facilitate relationships with the environment and access to certain resources (skills, finance, etc.). This underlines the importance of different conceptual frameworks in the analysis (Bammens et al., 2011 [115]).

Another important factor is the extension of the family, which further complicates the question of corporate governance. As the business evolves, subsequent generations take up the reins. Over time, the family loses its unity and homogeneity [99]. Divergent interests and disagreements appear. Conflicts surface when strategic and financial decisions have to be taken. Dividend policy is a typical example, where differences of opinion arise between family shareholders who prefer to reinvest profits in the business, and non-managerial, minority family shareholders who want a distribution of profits that provides them with an annuity. Such conflicts have a negative impact on the operation and efficiency of the Board. One of the challenges for family businesses is to find advisors who have the expertise and independence to act in the best interests of the company. These individuals should be able to define strategy and lay out general guidelines for the company; they should exercise genuine control over both the management and controlling shareholders (through appropriate mechanisms such as the audit) and ensure that the interests of minority shareholders are protected.

\subsection{Limitations and Future Research}

It is important to note that the results obtained are only valid in the context of the explanatory capacity of the selected variables and their operationalization. The research assesses the social responsibility of the organizations studied, and not the socially responsible behavior of the family members who control the capital of the business or have shareholdings. These people can, either in an individual or collective capacity, engage in responsible action at the societal level using their own financial resources and not those of the business. Family members can, of course, mobilize private funds to support causes they believe in: the environment, health, the protection of human rights, poverty reduction, the struggle against injustice, the development of local communities or support for local associations.

Our findings suggest two future avenues of research. On the one hand, it would be appropriate to broaden the scope of the analysis by identifying (in addition to the impact of the structure of ownership) other explanatory factors that may have a positive or negative impact on social responsibility. These may include the institutional, legal and regulatory environment, the cultural background, religious beliefs of management, and the history and traditions of the company. A comparison of listed and unlisted firms would enrich the analysis, as becoming listed naturally favors decisions oriented towards the interests of shareholders. The hypothesis that unlisted family firms have a greater social engagement with their stakeholders merits attention. The corporate governance model would be different in listed and unlisted companies, in particular familiness, "the unique set of resources of a family business which arise from the interactions between the family system as a whole, the individual family members, and the business itself" (Habbershon and Williams, 1999 [116]), would more be developed. It would be interesting to use different theoretical perspectives to inquire the diffusion of CSR among family SMEs, for example stewardship theory or social capital perspective, that seem to be more effective to understand the why and the how of CSR diffusion and/or relative obstacles in family firms. Similarly, it would be interesting to analyze the potential 
relationship between stakeholder engagement with the company (both familial and not) and the engagement of these same companies to their stakeholders. Qualitative methodologies, based on case studies and interviews with business leaders would be useful here. On the other hand, it would be relevant to examine the impact of social responsibility on the economic, financial, and stock performance of the company, and to identify, where appropriate, recursive causal links between social and financial performance. In the wake of research devoted to family businesses, the avenues opened up by CSR offer promising prospects.

\section{Acknowledgments}

The authors thank the VIGEO social responsibility rating agency for its support.

\section{Author Contributions}

The authors contributed equally in all aspects of the paper.

\section{Conflicts of Interest}

The authors declare no conflict of interest.

\section{References}

1. Friedman, M. The Social Responsibility of Business is to Increase its Profits. New York Times Magazine, 13 September 1970.

2. Lee, M.P.D. A review of the theories of corporate social responsibility: Its evolutionary path and the road ahead. Int. J. Manag. Rev. 2008, 10, 53-73.

3. Bowen, H.R. Social Responsibilities of the Businessman; Harper: New York, NY, USA, 1953.

4. Jones, T.M. Corporate social responsibility revisited, redefined. Calif. Manag. Rev. 1980, 22, 59-67.

5. Wartick, S.L.; Cochran, P.L. The evolution of the corporate social performance model. Acad. Manag. Rev. 1985, 10, 758-769.

6. Wood, D.J. Corporate Social Performance Revisited. Acad. Manag. J. 1991, 16, 691-718.

7. Blair, M. Ownership and Control: Rethinking Corporate Governance for the Twenty First Century; The Bookings Institution: Washington, DC, USA, 1996.

8. McWilliams, A.; Siegel, D. Corporate social responsibility: A theory of the firm perspective. Acad. Manag. Rev. 2001, 26, 117-127.

9. Margolis, J.D.; Walsh, J.P. Misery loves companies: Rethinking social initiatives by business. Adm. Sci. Q. 2003, 48, 268-305.

10. Makni, G.R.; Francoeur, C.; Bellavance, F. Causality between Corporate Social Performance and Financial Performance: Evidence from Canadian firms. J. Bus. Ethics 2009, 89, 409-422.

11. De la Cruz Déniz Déniz, M.; Cabrera Suarez, K. Corporate Social Responsibility and Family Business in Spain. J. Bus. Ethics 2005, 56, 27-41.

12. Dyer, W.G.; Whetten, D.A. Family Firms and Social Responsibility. Entrep. Theory Pract. 2006, 30, 785-802. 
13. Bingham, J.B.; Dyer, G.D.; Smith, I.; Adams, G.L. A Stakeholder Identity Orientation Approach to Corporate Social Performance in Family Firms. J. Bus. Ethics 2011, 99, 565-585.

14. Sharma, P.; Chrisman, J.J.; Chua, J.H. A Review and Annotated Bibliography of Family Business Studies; Kluwer Academic Publishers: Assinippi Park, MA, USA, 1996.

15. Neubauer, F.; Lank, A. The Family Business; McMillan Business: London, UK, 1998.

16. La Porta, R.; Lopez-de-Silanes, F.; Shleifer, A. Corporate ownership around the world. J. Financ. 1999, 54, 471-518.

17. Faccio, M.; Lang, L. The ultimate ownership of Western European Corporations. J. Financ. Econ. 2002, 65, 365-395.

18. Morck, R.; Yeung, B. Family control and the rent-seeking society. Entrep. Theory Pract. 2004, 28, 391-409.

19. Anderson, R.C.; Reeb, D.M. Founding Family Ownership and Firm Performance: Evidence from the SandP 500. J. Financ. 2003, 58, 1301-1328.

20. PricewaterhouseCoopers. L'entreprise Familiale, un Modèle Durable. Family Business SurveyFrance. Available online: http://www.pwc.com/gx/en/pwc-family-business-survey/assets/FBS 2010_11_FR.pdf (accessed on 15 June 2014).

21. Gomez-Mejia, L.R.; Cruz, C.; Berrone, P.; DeCastro, J. The bind that ties: Socioemotional wealth preservation in family firms. Acad. Manag. Ann. 2012, 5, 1-79.

22. Berrone, P.; Cruz, C.C.; Gómez-Mejía, L.R. Socioemotional wealth in family firms: A review and agenda for future research. Fam. Bus. Rev. 2012, 25, 258-279.

23. Cennamo, C.; Berrone, P.; Cruz, C.; Gomez-Mejia, L.R. Socioemotional Wealth and Proactive Stakeholder Engagement: Why Family-Controlled Firms Care More About Their Stakeholders. Entrep. Theory Pract. 2012, 1153-1173.

24. Miller, D.; le Breton-Miller, I.; Lester, R.H. Family firm governance, strategic conformity and performance: Institutional versus strategic perspectives. Organ. Sci. 2012, 24, 189-209, doi:10.1287/orsc. 1110.0728 .

25. Gomez-Mejía, L.R.; Haynes, K.T.; Núñez-Nickel, M.; Jacobson, K.J.L.; Moyano-Fuentes, H. Socioemotional wealth and business risk in family-controlled firms: Evidence from Spanish olive oil mills. Adm. Sci. Q. 2007, 52, 106-137.

26. Wiseman, R.M.; Gomez-Mejia, L.R. A Behavioral Agency Model of Managerial Risk Taking. Acad. Manag. Rev. 1998, 23, 133-153.

27. Lee, L. Social Responsibility and Economic Performance: An Empirical Examination of Corporate Profiles. Ph.D. Dissertation, US Alliant International University, San Diego, CA, USA, 1987.

28. Preston, L.; Post, J. Private Management and Public Policy; Prentice Hall: Upper Saddle River, NJ, USA, 1975.

29. Aguilera, R.V.; Rupp, D.E.; Williams, C.A.; Ganapathi, J. Putting the S back in corporate social responsibility: A multilevel theory of social change in organizations. Acad. Manag. Rev. 2007, 32, 836-863.

30. Waddock, S.A. Parallel universes: Companies, academics, and the progress of corporate citizenship. Bus. Soc. Rev. 2004, 109, 5-42.

31. Post, J. Corporate Behavior and Change; Reston Publishing Company: Reston, VA, USA, 1978. 
32. DeFillipi, R.J. Conceptual Framework and Strategies for Corporate Social Involvement Research. In Research in Corporate Social Performance and Policy; JAI Press: Greenwich, CT, USA, 1982.

33. Freeman, R.E. Strategic Management: A Stakeholder Approach; Cambridge University Press: Cambridge, UK, 1984.

34. Longo, M.; Mura, M.; Bonoli, A. Corporate Social Responsibility and Corporate Performance: The Case of Italian SMEs. Corp. Gov. 2005, 5, 28-42.

35. Abreu, R.; David, F.; Crowther, D. Corporate Social Responsibility in Portugal Empirical Evidence of Corporate Behavior. Corp. Gov. 2005, 5, 3-18.

36. Uhlaner, L.M.; van Goor-Balk, A.; Masurel, E. Family Business and Corporate Social Responsibility in a Sample of Dutch Firms. J. Small Bus. Enterp. Dev. 2004, 11, 186-194.

37. Papasolomou-Doukakis, I.; Krambia-Kapardis, M.; Katsioloudes, M. Corporate Social Responsibility: The Way Forward? Maybe Not! Eur. Bus. Rev. 2005, 17, 263-279.

38. Sharma, S. Managerial interpretations and organizational context as predictors of corporate choice of environmental strategy. Acad. Manag. Rev. 2000, 43, 681-697.

39. Mitchell, R.K.; Agle, B.R.; Wood, D.J. Toward a Theory of Stakeholder Identification and Salience: Defining the Principle of Who and What really Counts. Acad. Manag. Rev. 1997, 22, 853-886.

40. Mitchell, R.K.; Agle, B.R.; Chrisman, J.J.; Spence, L.J. Toward a Theory of Stakeholder Salience in Family Firms. Bus. Ethics Q. 2011, 21, 235-255.

41. Chrisman, J.J.; Chua, J.H.; Steier, L. Sources and Consequences of Distinctive Familiness: An introduction. Entrep. Theory Pract. 2005, 29, 237-247.

42. Pearson, A.W.; Carr J.C.; Shaw, J.C. Toward a Theory of Familiness: A Social Capital Perspective. Entrep. Theory Pract. 2008, 32, 949-969.

43. Gomez-Mejia, L.; Makri, M.; Larraza Kintana, M. Diversification decisions in Family-Controlled Firms. J. Manag. Stud. 2010, 47, 223-252.

44. Zellweger, T.M.; Nason, R.S. A Stakeholder Perspective on Family Firm Performance. Fam. Bus. Rev. 2008, 21, 203-216.

45. Berrone, P.; Cruz, C.C.; Gómez-Mejía, L.R.; Larraza Kintana, M. Socioemotional wealth and corporate responses to institutional pressures: Do family-controlled firms pollute less. Adm. Sci. $Q$. 2010, 55, 82-113.

46. Kets De Vries, M.F.R. The Entrepreneurial Personality: A Person at the Cross Roads. J. Manag. Stud. 1977, 14, 34-57.

47. Schein, E.H. The role of the founder in creating organizational culture. Organ. Dyn. 1983, 12, $13-28$.

48. Dyer, W.G., Jr. Cultural Change in Family Firms: Anticipating and Managing Business and Family Transitions; Jossey-Bass: San Francisco, CA, USA, 1986.

49. Chrisman, J.J.; Sharma, P.; Taggar, S. Family influences on family businesses: An introduction. J. Bus. Res. 2007, 60, 1005-1011.

50. Westhead, P.; Cowling, M.; Howarth, C. The development of family companies: Management and ownership imperatives. Fam. Bus. Rev. 2001, 14, 369-382. 
51. Brickson, S.L. Organizational identity orientation: Forging a link between organizational identity and organizations relations with stakeholders. Adm. Sci. Q. 2005, 50, 576-609.

52. Baron, R.A. The role of affect in the entrepreneurial process. Acad. Manag. Rev. 2008, 33, 328-340.

53. Jiao, Y. Stakeholder Welfare and Firm Value. J. Bank. Fin. 2010, 34, 2549-2561.

54. McGuire, J.; Dow, S.; Dow, S. All in the Family? Social Performance and Corporate Governance in the Family Firm. J. Bus. Res. 2012, 65, 1643-1650.

55. Fombrun, C.J. Reputation: Realizing Value from the Corporate Image; Harvard University Press: Cambridge, UK, 1996.

56. Tagiuri, R.; Davis, J.A. Bivalent Attributes of the Family Firm. Fam. Bus. Rev. 1996, 9, 199-208.

57. Chami, R. Whats Different About Family Businesses? IMF Working Paper IMF WP 01/70; Available online: http://www.imf.org/external/pubs/ft/wp/2001/wp0170.pdf (accessed on 2 January 2014).

58. Bourdieu, P. The Forms of Capital. In Handbook of Theory and Research for the Sociology of Education; Richardson, J.G., Ed.; Greenwood: New York, NY, USA, 1986; pp. 241-258.

59. Nahapiet, J.; Ghoshal, S. Social Capital, Intellectual Capital, and the Organizational Advantage. Acad. Manag. Rev. 1998, 23, 242-266.

60. Lyman, A.R. Customer service: Does family ownership make a difference? Fam. Bus. Rev. 1991, 4, 303-324.

61. Ward, J.L.; Aronoff, C.E. Trust gives you the advantage. Nations Bus. 1991, 79, 42-45.

62. Whetten, D.A.; Mackey, A. An Identity-Congruence Explanation of Why firms Would Consistently Engage in Corporate Social Performance; Working Paper; Brigham Young University: Provo, UT, USA, 2005.

63. Hogg, M.A. Social Identity. In Handbook of Self and Identity; Leary, M.R., Tangney, J.P., Eds.; Guilford Press: New York, NY, USA, 2003; pp. 462-479.

64. Hogg, M.A.; Terry, D.J. Social Identity Processes in Organizational Contexts; Psychology Press: Philadelphia, PA, USA, 2001.

65. Albert, S.; Whetten, D.A. Organizational Identity; Cummings, L.L., Staw, B.I.M., Eds.; Research in Organizational Behavior: JAI Press: Greenwich, CT, USA, 1985; Volume 7, pp. 263-295.

66. Sirmon, D.G.; Hitt, M.A. Managing Resources: Linking Unique Resources, Management, and Wealth Creation in Family Firms. Entrep. Theory Pract. 2003, 27, 339-358.

67. Sloan, P. Engagement des dirigeants envers les parties prenantes: Condition de succès du développement durable. Gest 2009, 1, 79-88.

68. Jamali, D. A Fresh Perspective into Theory and Practice. J. Bus. Ethics 2008, 82, 213-231.

69. Jamali, D.; Safieddine, A.M.; Rabbath, M. Corporate Governance and Corporate Social Responsibility Synergies and Interrelationships. Corp. Gov. 2008, 16, 443-459.

70. Koiranen, M. Over 100 years of Age but Still Entrepreneurially Active in Business: Exploring the Values and Family Characteristics of Old Finnish Family Firms. Fam. Bus. Rev. 2002, 175-188.

71. Aronoff, C. Self-Perpetuation Family Organization Built on Values: Necessary Condition for Long-Term Family Business Survival. Fam. Bus. Rev. 2004, 17, 55-59.

72. Tagiuri, R.; Davis, J. On the goals of successful family businesses. Fam. Bus. Rev. 1992, 5, 43-62. 
73. Allouche, J.; Amann, B. La confiance, une explication aux performances des entreprises familiales. Econ. Soc. 1998, 25, 129-154.

74. Steier, L. Family firms. Plural forms of governance, and the evolving role of trust. Fam. Bus. Rev. 2001, 14, 353-367.

75. Goffee, R.; Scase, R. Proprietorial Control in Family Firms: Some Functions of Quasi-organic Management Systems. J. Manag. Stud. 1985, 22, 53-68.

76. Poza, E.J.; Alfred, T.; Maheshwari, A. Stakeholder Perceptions of Culture and Management Practices in Family and Family Firms-A Preliminary Report. Fam. Bus. Rev. 1997, 10, 135-155.

77. James, H. Owner as Manager, Extended Horizons and the Family Firm. Int. J. Econ. Bus. 1999, $6,41-55$.

78. Hirigoyen, G. Concilier finance et management dans les entreprises familiales. Revue Française de Gestion 2009, 35, 393-411. (in French)

79. Monsen, J.R. Ownership and Management: The Effect of Separation on Performance. Bus. Horiz. 1969, 12, 46-52.

80. Astrachan, J.H. Family Firm and Community Culture. Fam. Bus. Rev. 1988, 1, 165-189.

81. Vallejo Martos, M.C.; Grande Torraleja, F.A. Is Family Business More Socially Responsible? The Case of GRUPO CIM. Bus. Soc. Rev. 2007, 112, 121-136.

82. Churchill, N.; Hatten, K. Nonmarket-based transfers of wealth and power: A research framework for family business. Am. J. Small Bus. Manag. 1987, 11, 51-64.

83. Crilly, D.; Zollo, M.; Hansen, M.T. Faking it or Muddling Through? Understanding Decoupling in Response to Stakeholder Pressures. Acad. Manag. J. 2012, 55, 1429-1448.

84. Westhead, P.; Cowling, M. Family firm research: The need for a methodological rethink. Entrep. Theory Pract. 1998, 23, 31-56.

85. Donnelley, R.G. The Family Business. Harv. Bus. Rev. 1964, 42, 93-105.

86. Barry, B. The Development of Organisation Structure in the Family Firm. J. Gen. Manag. 1975, 3, 42-60.

87. Beckhard, R.; Dyer, W.G. Managing Change in the Family Firm-Issues and Strategies. Sloan Manag. Rev. 1983, 24, 59-65.

88. Boswell, J. The Rise and Decline of Small Firms; George Allen and Unwin Ltd.: London, UK, 1972.

89. Chrisman, J.J.; Patel, P.C. Variations in R\&D Investments of Family and Nonfamily Firms: Behavioral Agency and Myopic Loss Aversion Perspectives. Acad. Manag. J. 2012, 55, 976-997.

90. McGuire, J.B.; Sundgren, A.; Schneeweis, T. Corporate social responsibility and firm financial performance. Acad. Manag. J. 1988, 31, 854-872.

91. Seifert, B.; Morris, S.A.; Bartkus, B.R. Comparing big givers and small givers: Financial correlates of corporate philanthropy. J. Bus. Ethics 2003, 45, 195-211.

92. Sraer, D.; Thesmar, D. Performance and behaviour of family firms: Evidence from the French stock market. J. Europ. Econ. Assoc. 2007, 5, 709-751.

93. Villalonga, B.; Amit, R. How do family ownership, control and management affect firm value? J. Financ. Econ. 2006, 80, 385-417.

94. La Porta, R.; Lopez-de-Silanes, F.; Shleifer, A.; Vishny, A. Legal determinants of external finance. J. Financ. 1997, 52, 1131-1150.

95. Aoki, M. The Cooperative Game Theory of the Firm; Oxford University Press: Oxford, UK, 1984. 
96. Uhlaner, L.M.; Berent-Braun, M.M.; Jeurissen, R.J.M.; de Wit, G. Beyond Size: Predicting Engagement in Environmental Management Practices for Dutch SMEs. J. Bus. Ethics 2012, 109, 411-429.

97. Block, J.H.; Wagner, M. The Effect of Family Ownership on Different Dimensions of Corporate Social Responsibility: Evidence from Large US Firms. Bus. Strategy Environ. 2013, doi:10.1002/bse.1798.

98. Sharma, P.; Sharma, S. Drivers of Proactive Environmental Strategy in Family Firms. Bus. Ethics $Q$. 2011, 21, 309-334.

99. Ward, J.L. Creating Effective Boards for Private Enterprise; Jossey-Bass Publishers: San Francisco, CA, USA, 1991.

100. Kellermanns, F.W.; Eddleston, K.A.; Zellweger, T.M. Extending the Socioemotional Wealth Perspective: A Look at the Dark Side. Entrep. Theory Pract. 2012, 36, 347-367.

101. Forgas, J.P. Mood and judgment: The affect infusion model. Psychol. Bull. 1995, 117, 39-66.

102. Loewenstein, G.; Adler, D. A bias in the prediction of tastes. Econ. J. 1995, 105, 929-937.

103. Mahérault, L. Comportement financier des entreprises familiales: Approche empirique. Economies et Sociétés 1999, 33, 247-272. (in French)

104. Bhattacharya, U.; Ravikumar, B. Capital Markets and Evolution of Family Businesses; Working Paper Series; Indiana University, Kelley School of Business: Indianapolis, IN, USA, 1999.

105. Basco, R.; Perez Rodriguez, M.J. Ideal Types of Family Business Management: Horizontal Fit between Family and Business Decisions and the Relationship with Family Business Performance. J. Fam. Bus. Strategy 2011, 2, 151-165.

106. Xiao, J.; Alhabeeb, M.; Hong, G.; Haynes, G. Attitude Toward Risk and Risk-Taking Behavior of Business-Owning Families. J. Consum. Aff. 2001, 35, 307-325.

107. Schulze, W.S.; Lubatkin, M.H.; Dino, R.N. Toward a Theory of Agency and Altruism in Family Firms. J. Bus. Ventur. 2003, 18, 473-490.

108. Habbershon, T.G.; Williams, M.; MacMillan, I.C. A unified systems perspective of family firm performance. J. Bus. Ventur. 2003, 18, 451-465.

109. Hirigoyen, G. Biais comportementaux dans l'entreprise familiale: Antécédents et impacts. Economies et Sociétés 2008, 19, 1901-1930. (in French)

110. O'Boyle, E.; Pollack, J.M.; Rutherford, M. Exploring the Relation between Family Involvment and Firms Performance: A Meta-Analysis of Main and Moderator Effects. J. Bus. Ventur. 2012, 27, 1-18.

111. Charreaux, G.; Pitol-Belin, J.P. Le Conseil D’administration; Vuibert: Paris, France, 1990. (in French)

112. Anderson, R.C.; Reeb, D.M. Board Composition: Balancing Family Influence in S\&P 500 Firms. Adm. Sci. Q. 2004, 49, 209-237.

113. Chau, G.; Leung, P. The Impact of Board Composition and Family Ownership on Audit Committee Formation: Evidence from Hong Kong. J. Int. Account. Audit. Tax. 2006, 15, 1-15.

114. Wernerfelt, B. A Resource-Based View of the Firm. Strat. Manag. J. 1984, 5, 171-180.

115. Bammens, Y.; Voordeckers, W.; van Gils, A. Boards of Directors in Family Businesses: A Literature Review and Research Agenda. Int. J. Manag. Rev. 2011, 13, 134-152. 
116. Habbershon, T.G.; Williams, M.L. A resource-based framework for assessing the strategic advantages of family firms. Fam. Bus. Rev. 1999, 12, 1-26.

(C) 2014 by the authors; licensee MDPI, Basel, Switzerland. This article is an open access article distributed under the terms and conditions of the Creative Commons Attribution license (http://creativecommons.org/licenses/by/3.0/). 